\title{
Influence of environmental factors onto reproductive characteristics of Daphnia galeata from Lake Baikal
}

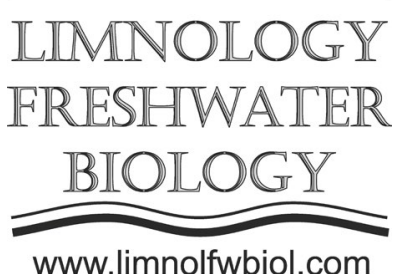

\author{
Pitul'ko S.I.
}

Limnological Institute of the Siberian Branch of the Russian Academy of Sciences, Ulan-Batorskaya Str., 3, Irkutsk, 664033, Russia

\begin{abstract}
The influence of various factors onto the reproductive characteristics of the cladoceran Daphnia galeata Sars, 1863 Lake Baikal was studied. With an increase in the concentration of available feed, the size of the body, average fertility, the size of the brood and the proportion of egg-bearing females increase. At high temperatures, significantly greater fecundity and the proportion of egg-bearing females were noted; other features did not change significantly with temperature increase. Under the conditions of strong turbulence, the fertility and the proportion of egg-bearing females are lower than under the conditions of low turbulence. The presence of a predator with an increase in the concentration of feed and temperature results in the decrease in the size of crustaceans and in the increase of the proportion of egg-bearing females.
\end{abstract}

Keywords: fertility, brood size, average fertility, proportion of egg-bearing females, feed, temperature, turbulence

\section{Introduction}

Daphnia are widely distributed in water bodies of various types; they serve as food for the higher links of the trophic chain. The biology, morphology and reproductive characteristics of these organisms are greatly influenced by various factors, such as the amount of available food, temperature, turbulence and among biotic factors - the influence of predators (nocturnal and invertebrates) (Zhukova, 1953; Jacobs, 1961; 1987; Gilyarov, 1987; Achenbach and Lampert, 1997; Laforsh and Tollrian, 2004; Dodson, 1988; Polishchuk and Vijverberg, 2006).

Among the above listed factors determining the animals' life activity, food is the most important one, in influences greatly onto the rate of reproduction, postnatal development, body size, eggs size and number, development of protective structures, life expectancy and development (Zhukova, 1953; Vijverberg, 1976; Gilyarov, 1987; Jacobs, 1987; Semenchenko, 1990; Burns, 1995; Boersma and Vijverberg, 1996; Czeczuga et al., 2003; Jeyasingh and Weider, 2005; Dodson, 1988; Polishchuk and Vijverberg, 2006; Manca et al., 2008). Under the laboratory conditions, major part of D. pulex clones cultivated at high food concentration manifest the increase of fertility and of crustaceans amount (Pitul'ko et al., 2009; Feniova et al., 2013).

The main food of planktonic crustaceans includes phytoplankton, detritus, bacteria, as well as protozoa. The size rank of objects is $3-30$ microns

*Corresponding author.

E-mail address: pitulko@inbox.ru (S.I. Pitulko)

Received: October 14, 2021; Accepted: October 26, 2021; Available online: November 29, 2021
(Monakov, 1998). Basically, for daphnia, these are small protococcal algae with a diameter of 3.5 microns, then Scenedesmus (15 microns) and Chlorococcum (20$30 \mu \mathrm{m})$, as well as species of the genus Chroomonas: Ch. acuta and Ch. sp. (7-11 $\mu \mathrm{m}$ long and 3-7 wide) and Stephanodiscus binderanus (7.5-12.3 $\mu \mathrm{m}$ in diameter), represented among the phytoplankton of Baikal. Algae of the genus Chroomonas dominate among lake phytoplankton (Bondarenko et al., 1991).

Temperature has a great influence onto the duration of embryogenesis, but influences less onto the growth after birth (Venkataraman and Job, 1980; Gilyarov, 1987). With an increase of temperature, metabolism and individual development of animals accelerate, respectively, egg maturation and reproduction accelerate (Deng, Xiea, 2003). More energy is required for the functioning of the organism and reproduction, hence the relative decrease in definitive sizes during accelerated puberty and reproduction, when the temperature in a water body increases (Achenbach and Lampert, 1997).

Turbulence is formed by the movement (flow) of water due to various reasons (wind, runoff, interaction of water layers with different temperatures or densities, moving organisms) (Jacobs, 1987; Laforsh and Tollrian, 2004; Tollrian and Laforsh, 2006). In summer, at optimal temperatures, increased turbulence results in the development of swimming-related problems (swimming antennas) and motion control: tail spine, helmet, carinea (Jacobs, 1961; 1962; 1987; Havel and

(C) Author(s) 2021. This work is distributed under the Creative Commons AttributionNonCommercial 4.0 International License. 
Dodson, 1985; Laforsh and Tollrian, 2004). Strong turbulence can hinder the food flow to food consumers, it weakens the distant detection of prey by a predator, increases the consumption of metabolic energy for movement and results in the decrease of fertility (Visser and Stips, 2002; Visser et al., 2008; Baranyai et al., 2011).

Size-selective predation, as well as substances secreted by the predator - kairomones, have a special effect onto cladoceran crustaceans. The presence of a predator results in morphological variability (cyclomorphosis) and various changes in fertility (Gilyarov, 1987; Jacobs, 1987; Burns, 1995; Jeyasingh and Weider, 2005; Dodson, 1988; Polishchuk and Vijverberg, 2006; Zuykova and Bochkarev, 2010).

The aim of the work is to analyze the effect of feed concentration, water temperature, turbulence on the reproductive characteristics of Daphnia galeata Sars, 1863 in Lake Baikal.

\section{Materials and methods}

D. galeata crustaceans were collected by a Djedi net (the area of the inlet is $0.1 \mathrm{~m} 2$, the mesh of the filter cone is 90 microns) in pelagic area and lake bays of Lake Baikal in August-September, 1993, 1995 and 1997 at 36 stations. The samples were fixed with $40 \%$ formalin. The main data were obtained for two large bays (Barguzin and Chivyrkuy - st. 18-33) and for the pelagic area of Central Baikal (st. 10-17). Data on the open coastal area and the Ushkany Islands area (st, 27), Selenginsk area (st. 8-9), the coastal zone of South Baikal (1-9), and coastal areas of North Baikal (st. 3436) were used.

The obtained samples of daphnia were divided into mature, pre-mature and juvenile females. A total of 25 individuals of $D$. galeata were studied. The total number of mature females, the number of egg-bearing females and the number of eggs in the brood chamber were calculated, the average fertility (the ratio of the sum of all eggs and embryos in brood bags to the number of mature females) and the average brood size obtained by dividing the total number of eggs and embryos to the number of egg-bearing females (Schultz and Sterner, 1999) were calculated.

To characterize the level of feed supply of daphnia, we will use the daily production of phytoplankton expressed in $\mathrm{mg}$ of carbon per $\mathrm{m}^{3}$ $\left(\mathrm{mg} \mathrm{C} / \mathrm{m}^{3}\right)$. This is an integrated indicator reflecting the amount of food in the habitats of daphnia. The materials available in the papers allow us to present the distribution of the number of bacterioplankton and phytoplankton included in the diet of lower crustaceans in Lake Baikal water area. Based on the data given in the work (Bondarenko et al., 1991), we identified six gradations for this indicator. Its lowest value $(19 \mathrm{mg}$ $\mathrm{C} / \mathrm{m}^{3}$ ) was registered in South Baikal. Stations 1-7 are assigned to this gradation. Further we studied the outlet parts of Barguzin and Chivyrkuy Bays, where feed concentrations for this indicator are very close to 35.0 and $30.0 \mathrm{mg} \mathrm{C} / \mathrm{m}^{3}$, therefore we combined samples

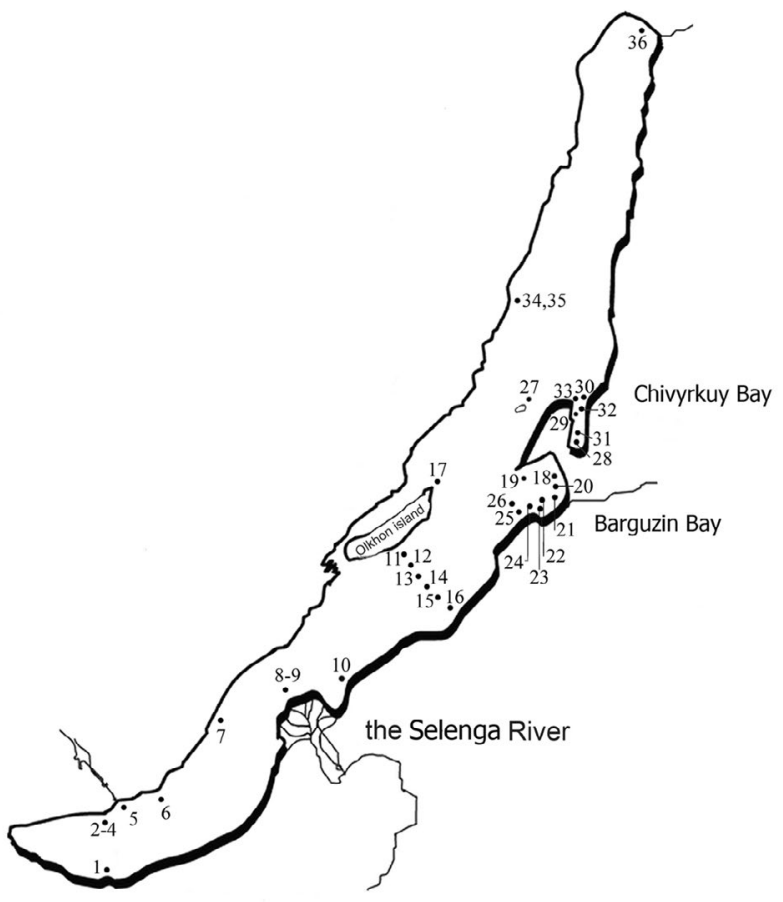

Fig.1. Stations of zooplankton sampling in Lake Baikal in 1993-1997. 1-7 - the coastal zone of South Baikal; 8-9 - the Selenginsk area; 10-17 - the pelagic area of Central Baikal; 18-26 - Barguzin bay; 27-33 - Chivyrkuy bay; 34-36 - the coastal areas of North Baikal.

from these areas into one gradation of $33 \mathrm{mg} \mathrm{C} / \mathrm{m}^{3}$ (st. 19, 25, 26, 30, 33). In Central and North Baikal, the daily production of phytoplankton according to this indicator is equal to $38 \mathrm{mg} \mathrm{C} / \mathrm{m}^{3}$ (st. 11-17, 27, 34-36). In the fourth gradation (the Selenginsk shallow water area), this indicator is $160 \mathrm{mg} \mathrm{C} / \mathrm{m}^{3}$ (st. 8-10). In the inner part of the Barguzin Bay it is $190 \mathrm{mg} \mathrm{C} / \mathrm{m}^{3}$ (st. 18, $20,22-24)$. The inner part of the Chivyrkuy Bay is 250 $\mathrm{mg} \mathrm{C} / \mathrm{m}^{3}$ (st. 28-29, 21-32). As follows from the above data, the selected gradations are divided into two qualitatively different groups. The values of the daily phytoplankton production index in the first three gradations are less than in the last three ones almost by one order of magnitude.

On the base of on the materials of long-term studies of seasonal changes in the temperature of the surface water layer, the following temperature levels were determined: North Baikal $-2.9^{\circ} \mathrm{C}$, Central Baikal - 3.2 ${ }^{\circ} \mathrm{C}$, South Baikal $-3.3{ }^{\circ} \mathrm{C}$, South Baikal, Barguzin strait, Chivyrkuy strait $-3.3^{\circ} \mathrm{C}$, Selenginsk shallow water area $-3.5{ }^{\circ} \mathrm{C}$, Barguzin inner area $-5.7{ }^{\circ} \mathrm{C}$, Chivyrkuy inner area $-7.1{ }^{\circ} \mathrm{C}$ (Bondarenko et al., 1991; Troitskaya et al., 2003).

The flow velocities of the surface water layer in the studied areas of the lake were taken from various sources, distributed as follows: Chivyrkuy and Barguzin inner areas - $1 \mathrm{~m} / \mathrm{s}$, South Baikal, North Baikal, Barguzin strait, Chivyrkuy strait $-2 \mathrm{~m} / \mathrm{s}$, South Baikal - $2.5 \mathrm{~m} / \mathrm{s}$, Central Baikal and Selenginsk shallow water area -3 m/s (Verbolov, 1977; Fialkov, 1983; Einbund, 1988; Shimaraev and Troitskaya, 2005). The studied samples are grouped according to the prevailing flow rates of the surface water layer. Each grouping, except the third, included samples (2.5) with a predator/ 
without a predator. In order to exclude the influence of other factors, the studied samples were divided into groups with maximum uniformity according to other factors studied. The first group included all samples, the second one only without a predator, the third one with a predator.

According to the data obtained, the average value of the attribute, the error of the average, was calculated. The differences were assessed using the Student's criterion, the significance levels are indicated: * - $\mathrm{P}<0.05$; ** $-\mathrm{P}<0.01$; *** $-\mathrm{P}<0.001$. (Rokitsky, 1973).

\section{Results}

The effect of the amount of available feed on the reproductive characteristics of populations of D. galeata. One of the most important population characteristics is the average fertility, or the number of offspring per mature female. In D. galeata, according to all available data, the average fertility is significantly higher at high feed concentrations $(\mathrm{P}<0.001)$ (Table). The regression coefficient was $0.004 \pm 0.0007(\mathrm{t}=$ 5.42; $\mathrm{P}<0.001)$. Under these conditions, the average value of mature females is significantly higher at high feed concentrations $(\mathrm{P}<0.05)$. In predator-free conditions, the length of mature females is significantly longer at high feed concentrations $(P<0.01)$. In the samples without a predator, the average fertility is significantly higher at high feed concentrations $(\mathrm{P}<$ $0.05)$. The regression coefficient is $0.0003 \pm 0.0012$ $(\mathrm{t}=2.68 ; \mathrm{P}<0.05)$. Under the conditions with a predator, the size of mature females is significantly smaller at high feed concentrations $(<0.001)$, but there are no differences in fertility at low and high feed concentrations.

According to all available data, D. galeata (Table) at high concentrations, the brood size is significantly higher $(\mathrm{P}<0.001)$. Under the conditions without a predator at high feed concentrations, the size of the brood does not differ. In the presence of a predator, with an increase in feed concentrations, the brood size decreases $(\mathrm{P}<0.05)$. The regression coefficient is $-0.004 \pm 0.0010(\mathrm{t}=3.49 ; \mathrm{P}<0.001)$.

The proportion of egg-bearing females in all variants of our study is greater at high feed concentrations (Table). Under the conditions without a predator, at low feed concentrations, the smallest number of egg-bearing females was obtained, and the largest one was at high concentrations. In the presence

Table. The effect of feed quantity, temperature and turbulence onto the reproductive characteristics of Daphnia galeata

\begin{tabular}{|c|c|c|c|c|c|c|}
\hline \multirow[t]{3}{*}{ Characteristics } & \multicolumn{6}{|c|}{ Analysis options } \\
\hline & \multicolumn{2}{|c|}{ All data } & \multicolumn{2}{|c|}{ Without predators } & \multicolumn{2}{|c|}{ With predator } \\
\hline & \begin{tabular}{|c|} 
Low food \\
concentration \\
$(19-38 \mathrm{mg}$ \\
$\left.\mathrm{C} / \mathrm{m}^{3}\right)$
\end{tabular} & $\begin{array}{c}\text { High food } \\
\text { concentration } \\
(160-250 \mathrm{mg} \\
\left.\mathrm{C} / \mathrm{m}^{3}\right)\end{array}$ & $\begin{array}{c}\text { Low food } \\
\text { concentration } \\
(19-38 \mathrm{mg} \\
\left.\mathrm{C} / \mathrm{m}^{3}\right)\end{array}$ & $\begin{array}{c}\text { High food } \\
\text { concentration } \\
(160-250 \mathrm{mg} \\
\left.\mathrm{C} / \mathrm{m}^{3}\right)\end{array}$ & $\begin{array}{c}\text { Low food } \\
\text { concentration } \\
(19-38 \mathrm{mg} \\
\left.\mathrm{C} / \mathrm{m}^{3}\right)\end{array}$ & $\begin{array}{c}\text { High food } \\
\text { concentration } \\
(160-250 \mathrm{mg} \\
\left.\mathrm{C} / \mathrm{m}^{3}\right)\end{array}$ \\
\hline $\begin{array}{c}\text { Number of studied } \\
\text { individuals }\end{array}$ & 818 & 405 & 595 & 78 & 223 & 327 \\
\hline Body length $(\mu \mathrm{m})$ & $948.2 \pm 4.14$ & $965.1 \pm 6.01 *$ & $927.2 \pm 4.82$ & $976.4 \pm 15.91 * *$ & $1004.3 \pm 6.81$ & $962.4 \pm 6.40 * * *$ \\
\hline Average fertility & $1.91 \pm 0.079$ & $2.64 \pm 0.111^{* * *}$ & $1.55 \pm 0.08$ & $2.10 \pm 0.209^{*}$ & $2.86 \pm 0.177$ & $2.75 \pm 0.127$ \\
\hline Average brood size & $3.25 \pm 0.096$ & $3.42 \pm 0.110$ & $2.80 \pm 0.106$ & $2.73 \pm 0.212$ & $4.14 \pm 0.178$ & $3.59 \pm 0.124^{*}$ \\
\hline $\begin{array}{l}\text { Proportion of egg-bearing } \\
\text { females }\end{array}$ & 58.8 & 76.8 & 55.5 & 76.9 & 69.1 & 76.8 \\
\hline Temperature & \begin{tabular}{|c|} 
Low temperature \\
$\left(2.9-3.5{ }^{\circ} \mathrm{C}\right)$
\end{tabular} & $\begin{array}{c}\text { High } \\
\text { temperature } \\
\left(5.7-7.1{ }^{\circ} \mathrm{C}\right)\end{array}$ & $\begin{array}{c}\text { Low temperature } \\
\left(2.9-3.5{ }^{\circ} \mathrm{C}\right)\end{array}$ & $\begin{array}{l}\text { High } \\
\text { temperature } \\
\left(5.7-7.1^{\circ} \mathrm{C}\right)\end{array}$ & \begin{tabular}{|c|} 
Low temperature \\
$\left(2.9-3.5{ }^{\circ} \mathrm{C}\right)$
\end{tabular} & $\begin{array}{l}\text { High temperature } \\
\quad\left(5.7-7.1{ }^{\circ} \mathrm{C}\right)\end{array}$ \\
\hline $\begin{array}{l}\text { Number of studied } \\
\text { individuals }\end{array}$ & 944 & 279 & 624 & 49 & 320 & 228 \\
\hline Body length $(\mu \mathrm{m})$ & $953.5 \pm 3.84$ & $954.9 \pm 7.50$ & $930.5 \pm 4.75$ & $965.1 \pm 21.03$ & $998.3 \pm 5.74$ & $953.2 \pm 7.86^{* * *}$ \\
\hline Average fertility & $1.97 \pm 0.075$ & $2.76 \pm 0.132 \% * *$ & $1.55 \pm 0.80$ & $2.41 \pm 0.257 * * *$ & $2.79 \pm 0.146$ & $2.84 \pm 0.151$ \\
\hline Average brood size & $3.33 \pm 0.088$ & $3.33 \pm 0.132$ & $2.82 \pm 0.103$ & $2.74 \pm 0.254$ & $4.12 \pm 0.144$ & $3.44 \pm 0.150^{* * *}$ \\
\hline $\begin{array}{c}\text { Proportion of egg-bearing } \\
\text { females }\end{array}$ & 59.3 & 83.8 & 55.1 & 87.8 & 67.5 & 82.9 \\
\hline Turbulence intensity & $\begin{array}{c}\text { Low turbulence } \\
(1-2 \mathrm{~m} / \mathrm{s})\end{array}$ & $\begin{array}{c}\text { High } \\
\text { turbulence } \\
(2.5-3 \mathrm{~m} / \mathrm{s})\end{array}$ & $\begin{array}{l}\text { Low turbulence } \\
\quad(1-2 \mathrm{~m} / \mathrm{s})\end{array}$ & $\begin{array}{c}\text { High } \\
\text { turbulence }(2.5-3 \\
\mathrm{m} / \mathrm{s})\end{array}$ & $\begin{array}{l}\text { Low turbulence } \\
(1-2 \mathrm{~m} / \mathrm{s})\end{array}$ & $\begin{array}{l}\text { High } \\
\text { turbulence } \\
(2.5-3 \mathrm{~m} / \mathrm{s})\end{array}$ \\
\hline $\begin{array}{c}\text { Number of studied } \\
\text { individuals }\end{array}$ & 939 & 282 & 326 & 282 & 548 & 0 \\
\hline Body length $(\mu \mathrm{m})$ & $958.4 \pm 3.86$ & $938.5 \pm 7.28 *$ & $928.8 \pm 6.11$ & $938.5 \pm 7.28$ & $972.7 \pm 6.46$ & - \\
\hline Average fertility & $2.31 \pm 0.076$ & $1.59 \pm 0.120 * * *$ & $1.87 \pm 0.116$ & $1.59 \pm 0.120$ & $2.80 \pm 0.104$ & - \\
\hline Average brood size & $3.41 \pm 0.082$ & $2.87 \pm 0.153^{* *}$ & $2.48 \pm 0.122$ & $2.89 \pm 0.153$ & $3.80 \pm 0.103$ & - \\
\hline $\begin{array}{l}\text { Proportion of egg-bearing } \\
\text { females }\end{array}$ & 67.6 & 53.3 & 61.7 & 55.0 & 73.7 & - \\
\hline
\end{tabular}


of a predator at all feed concentrations, the proportion of egg-bearing females is higher than in samples without a predator. Under the conditions with a predator, there are more egg-bearing females at low feed concentrations than under the conditions without a predator, slightly more than at high feed concentrations. Consequently, the number of egg-bearing females is influenced by two factors, food and predator.

Thus, over the entire data set and under the conditions without a predator, the fertility increases with an increase of the concentration of available food. At presence of a predator, there are no differences between fertility at different feed concentrations. The average brood size at all feed concentrations does not differ across the entire data set and under the conditions without a predator. Under the conditions with a predator, the average size of the brood is larger at low feed concentrations, and at high body length and the size of the hatch become smaller, and the proportion of egg-bearing females increases. Changes in the first two features result from size-selective predation, an increase in the proportion of egg-bearing females is a selective response that allows maintaining the population size.

The influence of temperature onto the reproductive characteristics of daphnia populations. Over the entire data set, the average fertility was significantly $(\mathrm{P}<0.001)$ higher at high temperatures (Table). The value of the regression coefficient was $2.94 \pm 0.644(\mathrm{t}=4.56 ; \mathrm{P}<0.001)$. In the samples without a predator, a significant stimulating effect of temperature on fertility was also noted $(\mathrm{P}<0.001)$. The regression coefficient is $0.24 \pm 0.073(\mathrm{t}=3.24$; $\mathrm{P}<0.001)$. According to all available data, and under the conditions without a predator, there are no differences in body length under the conditions of low and high temperatures. In the presence of a predator, the size of adult females is significantly smaller at high temperatures $(\mathrm{P}<0.001)$, and there are no differences in fertility in daphnia from low and high temperatures. Nevertheless, in the presence of a predator at the studied temperatures, fertility is higher than under the conditions without a predator.

In the whole data set and under the conditions without a predator at low and high feed concentrations, the average brood size does not differ in values (Table). At presence of a predator, on the contrary, there is a significant decrease in the brood size $(\mathrm{P}<0.001)$. The regression coefficient was $-0.19 \pm 0.06(\mathrm{t}=3.56$; $\mathrm{P}<$ 0.001).

One of the important characteristics of the population is the proportion of mature females simultaneously participating in reproduction. The proportion of mature females in the whole data set and under the conditions without a predator is greater at high temperatures. At the presence of a predator, the proportion of egg-bearing females is slightly higher at high temperatures, and at low temperatures, the proportion of females at greater in the presence of a predator than under the conditions without a predator. Consequently, the reproductive potential of the population is influenced by both studied factors.
The average fertility under the conditions without a predator is greater at high temperatures than at low ones. At the presence of a predator, there are no differences in fertility between high and low temperatures, but the average fertility under these conditions is greater than under the conditions without a predator. Average fertility is associated with the proportion of egg-bearing females, and the size of the brood depends on the size of the body. Under the conditions without a predator and at high temperatures, there are more crustaceans than at low temperatures. At absence of a predator, the size of the brood, on the contrary, does not depend on the temperature under the conditions without a predator. At presence of a predator at high temperatures, crustaceans are smaller than at low temperatures. Under these conditions, under the conditions without a predator, the size of the brood, on the contrary, does not depend on the temperature under conditions without a predator. At low temperatures, the proportion of egg-bearing females is higher than under the conditions without a predator, but lower at high temperatures.

Consequently, a temperature increase under the conditions without a predator positively affects the size of mature crustaceans, there is an increase in average fertility and in the proportion of egg-bearing females. The temperature does not have a pronounced effect on the size of the brood. At the presence of a predator, the size of the brood and the proportion of egg-bearing females are greater at low temperatures.

The effect of turbulence onto reproductive characteristics. Over the entire data set, D. galeata's average fertility is significantly lower with high turbulence $(P<0.001)$. Under these conditions, the size of mature females is much smaller with high turbulence $(P<0.05)$. In the samples without a predator, there is a slight decrease in fertility, and there are no significant differences in the number of mature females. In samples with a predator with a high level of turbulence, fertility is significantly lower $(\mathrm{P}<0.05)$. The regression coefficient was $-0.46 \pm 0.207(\mathrm{t}=2.22$; $\mathrm{P}<0.05)$. At presence of a predator, the size of mature females is slightly larger with high turbulence.

The average brood size in the whole data set is significantly higher at a low water flow rate of $-0.18 \pm$ $0.166(\mathrm{t}=1.08 ; \mathrm{P}<0.001)$ (Table). The regression coefficient is $-0.67 \pm 0.099(\mathrm{t}=6.80 ; \mathrm{P}<0.001)$. In the samples without a predator, there are no differences in the average size of the brood. At the presence of a predator, the average brood size does not differ at different levels of turbulence.

The proportion of egg-bearing females in all variants of the analysis (in the whole data set and under the conditions without a predator and with a predator) is greater at low water flow rates (Table). At presence of a predator, regardless the flow rates, the proportion of egg-bearing females is higher than under the conditions without a predator.

As it can be seen from the results presented above, the effect of water turbulence onto the productive characteristics of D. galeata is negative. Average fertility 
is always lower at high water flow rates. At presence of a predator, the average fertility is significantly higher with low turbulence, compared to conditions without a predator. The average brood size at presence of a predator at all levels of turbulence is larger than under the conditions without a predator. The proportion of egg-bearing females is smaller at high water flow rates, but is always higher under the conditions with a predator than under the conditions without a predator. Thus, of all the analyzed factors, predators availability is the strongest one.

\section{Discussion}

The results obtained showed that fertility increases in the whole data set and under the conditions without a predator with an increase in the concentration of available food. The average brood size at all food concentrations does not differ in the whole the entire data set and under the conditions without a predator. At presence of a predator at high levels of turbulence, the average fertility is significantly less, the proportion of egg-bearing females increases. We have the right to assume that this is results directly from selective influence of the predator, which caused a significant decrease in the body size of mature females at high food concentrations, and this results in a decrease of fertility and size of the brood. Invertebrate predators consume small crustaceans, their pressure affects the number of pre-mature and small adult crustaceans. Largesized adult crustaceans have a multiple advantage, since on the one hand they can accumulate large food reserves and produce large broods, on the other hand they are inaccessible to a predator. Thus, the birth rate increases, and some of the new crustaceans reach their adulthood and have time to leave an offspring. As it was shown in our work (Korzun and Pitul'ko, 2010), under the conditions of low concentration of food, the density of the predator is small and the temperature and concentration of food play the greatest role. At high food concentrations and a large number of predators, intensive size-selective predation is observed; it results in the fact that daphnia begin to multiply at smaller sizes, and this results in to a decrease of the amount of yield and average fertility. Such responses have been shown previously for natural and laboratory populations (Vijverberg, 1976; Czeczuga, et al., 2003; Boersma and Vijverberg, 1996; Polishchuk and Vijverberg, 2006; Heungens et al., 2006). With large quantities, food ceases to be a limiting factor, and all resources are used to increase the number of eggs and somatic growth, large crustaceans have a greater number of descendants (Polishchuk and Vijverberg, 2006).

In Lake Baikal, temperature increase up to the maximum observed values has a positive effect onto reproductive characteristics. The greatest increase of average fertility and the proportion of egg-bearing females was observed under the conditions without a predator. At high temperatures, the average fertility and the proportion of egg-bearing females significantly increase. The size of the body increases slightly, and the size of the brood remains unchanged. A similar response is observed in terms of body size, with large crustaceans present at high temperatures, especially under the conditions without a predator. At presence of a predator, the average fertility and the size of the brood greatly increase. It should be noted that under these conditions, a large brood size is observed at low temperatures. The proportion of egg-bearing females abruptly increased at low concentrations but not as much as under the conditions without a predator at high concentrations. Thus, the influence of the predator in many cases is more significant than the influence of temperature. The usual reaction of cladocerans to an increase of temperature is an acceleration of growth and development in the pre-mature stages and is maximally recorded at high food concentrations (Deng and Xiea, 2003; Heungens et al., 2006). Thus, it is possible to note the specifics observed in Lake Baikal, given that the water temperature reaches optimal for $D$. galeata only near the shores and in closed bays and coves. At high temperatures, under the conditions without a predator, an increase in body size was noted. It should be noted that in Lake Baikal, the water temperature rarely reaches optimal values for $D$. galeata. At presence of a predator, the sizes of bodies and broods decrease, while the proportion of egg-bearing females increases.

The results presented above clearly show the negative effect of water turbulence onto the reproductive characteristics of $D$. galeata. The average fertility, the size of the brood and the proportion of egg-bearing females are lower with high turbulence than with low one. In the presence of a predator, the average fertility is high at low turbulence and decreases at high speeds, while remaining higher than under the conditions without a predator. It should be noted that the conditions of severe turbulence are presented in areas with low values of other factors (food and temperature), so the observed results may result from their combined action. The average brood size at presence of a predator does not depend on turbulence and is greater than under the conditions without a predator. The proportion of egg-bearing females is always lower at high water flow rates, but under the conditions with a predator, it is higher than under the conditions without a predator. Under these conditions, there is no sufficiently pronounced effect onto body size. The decrease in the size of the body is presented only with high turbulence over the entire data array.

Thus, it can be noted that the influence of the predator is more important than the influence of turbulence. In addition, other factors studied (the amount of available food and water temperature), as well as the predator, have a greater influence onto population characteristics than turbulence.

\section{Conclusions}

An increase of amount of available food and of temperature have a significant positive effect onto all the studied reproductive characteristics (fertility, brood size, the proportion of egg-bearing females) in 
D. galeata. The fertility and the size of the brood are determined by food and temperature. At the same time, the smallest response is in the size of the brood. At high feed concentrations, an increase in body size, fertility and the proportion of egg-bearing females was noted.

The influence of the predator stimulates the reproduction of the population by increasing the number of egg-bearing females. In addition, an invertebrate predator results in a decrease in the size of mature females and the size of the brood.

Turbulence in all cases has a negative effect, sometimes reduced by the presence of a predator. In the presence of a predator at low levels of turbulence, the average fertility and the proportion of egg-bearing females are higher, with a high level of turbulence, the fertility and the proportion of egg-bearing females decrease.

\section{Acknowledgments}

We thank V.M. Korzun for the help, advice and friendly criticism during the work on the manuscript and Julia Kaplyukova for translation of the manuscript from Russian into English. The work is performed within the project no. 51.1.1.10 "State, biodiversity and ecology of the coastal zone of Lake Baikal." (O.A. Timoshkin).

\section{Conflict of interests}

The author declares no conflict of interests.

\section{References}

Achenbach L., Lampert W. 1997. Effects of elevated temperatures on threshold food concentrations and possible competitive abilities of differently sized cladoceran species. Oicos 79(3): 469-476. DOI: 10.2307/3546889

Baranyai E., G.-Toth L., Vari A. et al. 2011. The effect of variable turbulent intensities on the distribution of zooplankton in the shallow, large Lake Balaton (Hungary). Knowledge and Management of Aquatic Ecosystems 40(400): 17-20. DOI: $10.1051 / \mathrm{kmae} / 2011003$

Boersma M., Vijverberg J. 1996. Food effects on life history traits and seasonal dynamics of Ceriodaphnia pulchella. Freshwater Biology 35(1): 25-34. DOI: 10.1046/j.1365-2427.1996.00478.x

Bondarenko N.A., Grachev M.A., Zemskaya T.I. et al. 1991. ATP content in microplankton in some areas of Lake Baikal. Ekologiya [Ecology] 6: 47-56. (in Russian)

Burns C.W. 1995. Effects of crowding in different food levels on growth and reproductive investment of Daphnia. Oecologia 101(2): 234-244. DOI: 10.1007/BF00317289

Czeczuga B., Kozłowska M., Kiziewicz B. 2003. Effect of various types of phytoplankton on fertility, egg size and duration of postembryonic growth of a few plankton representatives of Cladocera (Crustacea). Polish Journal of Environmental Studies 12(5): 545-555.

Deng D., Xiea P. 2003. Effect of food and temperature on the growth and development of Moina irrasa (Cladocera: Moinidae). Journal of Freshwater Ecology 18(4): 503-513. DOI: 10.1080/02705060.2003.9663991

Dodson S.I. 1988. Cyclomorphosis in Daphnia galeata mendotae Birge and $D$. retrocurva Forbes as a predator-induced response. Freshwater Biology 19(1): 109-114. DOI: 10.1111/ j.1365-2427.1988.tb00332.x

Einbund M.M. 1988. Techeniya i vnutrenniy vodoobmen $\mathrm{v}$ ozere Baikal [Currents and internal water exchange in Lake Baikal]. Leningrad: Hydrometeoizdat. (in Russian)

Feniova I.Yu., Palash A.L., Razlutskij V.I. et al. 2013. Effects of temperature and resource abundance on small- and large-bodied cladocerans: community stability and species replacement. Open Journal of Ecology 3(2): 164-171. DOI: 10.4236/oje.2013.32020

Fialkov V.A. 1983. Techeniya pribrezhnoy zony ozera Baikal [Currents of the coastal zone of Lake Baikal]. Novosibirsk: Nauka. (in Russian)

Gilyarov A.M. 1987. Dinamika chislennosti presnovodnykh planktonnykh rakoobraznykh [Dynamics of the abundance of freshwater planktonic crustaceans]. Moscow: Nauka. (in Russian)

Havel J.E., Dodson S.I. 1985. Environmental cues for cyclomorphosis in Daphnia retrocurva. Freshwater Biology 15(4): 469-478.

Heungens E.H.W., Tokkie L.T.B., Kraak M.H.S. et al. 2006. Population growth of Daphnia magna under multiple stress conditions: joint effect of temperature, food, and cadmium. Environmental Toxicology and Chemistry 25(5): 1399-1407. DOI: $10.1897 / 05-294 R .1$

Jacobs J. 1961. Cyclomorphosis in Daphnia galeata mendotae Birge, a case of environmentally controlled allometry. Archiv für Hydrobiologie 58: 7-71.

Jacobs J. 1962. Light and turbulence as co-determinants of relative growth rates. Internationale Revue der gesamten Hydrobiologie und Hydrographie [International Review of the Entire Hydrobiology and Hydrography] 47(1): 146-156. (in German)

Jacobs J. 1987. Cyclomorphosis in Daphnia. In: Peters R.H., de Bernardi R. (Eds.), Daphnia: memorie dell'Istituto Italiano di Idrobiologia: Dott. Marco De Marchi. Italy: Consiglio Nazionale, pp. 325-352.

Jeyasingh P.D., Weider L.J. 2005. Phosphorus availability mediates plasticity in life-history traits and predator-prey interactions in Daphnia. Ecology Letters 8(10): 1021-1028. DOI: $10.1111 /$ j.1461-0248.2005.00803.x

Korzun V.M., Pitul'ko S.I. 2010. Phenotypic variation and adaptive reaction to the presence of predator in two Daphnia species (Daphniiformes, Daphnia) in Lake Baikal. Russian Journal of Ecology 41(4): 316-321. DOI: 10.1134/ $\underline{\mathrm{S} 1067413610040065}$

Laforsh Ch., Tollrian R. 2004. Extreme helmet formation in Daphnia cucullata induced by small-scale turbulence. Journal of Plankton Research 26(1): 81-87. DOI: 10.1093/ plankt/fbg114

Manca M., Vijverdtrg J., Polishuk V. et al. 2008. Daphnia body size and population dynamics under predation by invertebrate and fish predators in Lago Madjiore: an approach based on contribution analysis. Journal of Limnology 67(1): 15-21. DOI: $10.4081 /$ jlimnol.2008.15

Monakov A.I. 1998. Pitaniye presnovodnykh bespozvonochnykh [Feeding of freshwater invertebrates]. Moscow: A.N. Severtsov Institute of Ecological and Evolutional Problems of RAS. (in Russian)

Pitul'ko S.I., Yermakov Ye.L., Korzun V.M. 2009. Variability of Daphnia clonal cultures by a set of quantitative features under contrast feeding conditions. Izvestiya Irkutskogo Gosudarstvennogo Universiteta. Seriya "Biologiya. Ekologiya" [The Bulletin of Irkutsk State University. Series "Biology. Ecology"] 2(2): 83-86. (in Russian)

Polishchuk L.V., Vijverberg J. 2006. Body mass dynamics of Daphnia in the context of life history theory: an approach based on contribution analysis. Zhurnal Obshchei Biologii [Biology Bulletin Reviews] 61(1): 23-36. (in Russian) 
Rokitsky P.F. 1973. Biologicheskaya statistika [Biological statistics]. Minsk: Vysshaya Shkola. (in Russian)

Schultz K.L., Sterner R.W. 1999. Phytoplankton phosphorus limitation and food quality for Bosmina. Limnology and Oceanography 44(6): 1549-1556.

Semenchenko V.P. 1990. Comparative analysis of reproduction strategies in Cladocera at different food concentration. Zhurnal Obshchei Biologii [Biology Bulletin Reviews] 51(6): 828-835. (in Russian)

Shimaraev M.R., Troitskaya E.S. 2005. Seasonal features of geostrophic currents in southern Baikal. Geografiya i Prirodnye Resursy [Geography and Natural Resources] 1: 58-65. (in Russian)

Tollrian R., Laforsh Ch. 2006. Linking predator kairomones and turbulence: synergistic effects and ultimate reasons for phenotypic plasticity in Daphnia cucullata. Archiv für Hydrobiologie 176(1-4): 135-146. DOI: 10.1127/0003-9136/2006/0167-0135

Troitskaya E.S., Shimaraev M., Tsekhanovsky V.V. 2003. Long-term changes in water surface temperature in Baikal. Geografiya i Prirodnye Resursy [Geography and Natural Resources] 2: 47-50. (in Russian)

Venkataraman K., Job S.V. 1980. Effect of temperature on the development, growth and egg production in Daphnia carinata King (Cladocera-Daphniidae). Hydrobiologia 68(3): 217-224. DOI: $\underline{10.1007 / \mathrm{BF} 00018829}$
Verbolov V.I. 1977. General characteristics of navigation period currents. In: Afanas'ev A.N. (Ed.), Techeniya v Baikale [Currents in Baikal]. Novosibirsk: Nauka, pp. 43-62. (in Russian)

Vijverberg J. 1976. The effect of food quantity and quality on the growth, birth-rate and longevity of Daphnia hyalina Leydig. Hydrobiologia 51(2): 99-108. DOI: 10.1007/ BF00009824

Visser A.W., Mariani P., Pigolotti S. 2008. Swimming in turbulence: zooplankton fitness in terms of foraging efficiency and predation risk. Journal of Plankton Research 31(2): 121-133. DOI: $10.1093 /$ plankt/fbn109

Visser A.W., Stips A. 2002. Turbulence and zooplankton production: insights from PROVESS. Journal of Sea Research 47(3): 317-329. DOI: $10.1016 /$ S1385-1101(02)00120-X

Zhukova N.A. 1953. Cyclomorphosis in daphnia. Uchenyye Zapiski Leningradskogo Pedagogicheskogo Instituta [Scientific Notes of the Leningrad Pedagogical Institute] 7: 85-148. (in Russian)

Zuykova E.I., Bochkarev N.A. 2010. Postembryonal morphological variation of Daphnia galeata in water bodies of different types. Contemporary Problems of Ecology 3(1): 28-40. DOI: $10.1134 /$ S1995425510010066 